\title{
Energy-modulating vitamins - a new combinatorial therapy prevents cancer cachexia in rat mammary carcinoma
}

\author{
Selvanathan Saravana Perumal ${ }^{1}$, Palanivelu Shanthi ${ }^{2}$ and Panchanadham Sachdanandam ${ }^{1} *$ \\ ${ }^{1}$ Department of Medical Biochemistry and \\ ${ }^{2}$ Department of Pathology, Dr AL Mudaliar Post Graduate Institute of Basic Medical Sciences, University of Madras, Taramani Campus, \\ Chennai 600 113, India
}

(Received 29 October 2004 - Revised 23 January 2005 - Accepted 25 January 2005)

\begin{abstract}
Mitochondria are the major intracellular organelles producing ATP molecules via the electron transport chain. Cancer cells have a deviant energy metabolism, and a high rate of glycolysis is related to a high degree of dedifferentiation and proliferation. The overall net ATP production is diminished with cancer, which ultimately leads to cancer cachexia. The present study was designed to investigate the altered energy metabolism in cancer cells and to enhance ATP production in the normal host cell metabolism by enhancing the activities of mitochondrial enzymes, using energy-modulating vitamins, and thus prevent cancer cachexia. Female Sprague-Dawley rats were selected for the experimental study. Mammary carcinoma was induced by the oral administration of 7,12-dimethylbenz[a]anthracene $(25 \mathrm{mg} / \mathrm{kg}$ body weight), and treatment was started by the oral administration of the energy-modulating vitamins riboflavin $\left(45 \mathrm{mg} / \mathrm{kg}\right.$ body weight per d), niacin ( $100 \mathrm{mg} / \mathrm{kg}$ body weight per d) and coenzyme $\mathrm{Q}_{10}(40 \mathrm{mg} / \mathrm{kg}$ body weight per d) for $28 \mathrm{~d}$. Mitochondria were isolated from the mammary gland and liver of all four groups, and the Krebs cycle and oxidative phosphorylation enzymes were assayed. In mammary carcinoma-bearing animals, the activities of the Krebs cycle and oxidative phosphorylation enzymes were significantly decreased. These activities were restored to a greater extent in animals treated with energy-modulating vitamins. From these experimental results, one may hypothesize that the combination therapy of energy-modulating vitamins could be of major therapeutic value in breast cancer.
\end{abstract}

Breast cancer: Energy-modulating vitamins: Mitochondrial enzymes: Cancer cachexia

Mitochondria are the major intracellular organelles producing ATP molecules via the electron transport chain (ETC), which is essential for major metabolic processes such as biosynthesis, active transport and DNA repair (Singh, 2000). Under normal aerobic conditions, the cells derive their energy primarily from oxidative phosphorylation via oxidation through the Krebs cycle. In cancerous conditions, the cancer cells use an anaerobic energy cycle, meaning that they do not depend upon $\mathrm{O}_{2}$ to sustain themselves (Pederson, 1978; Baggetto, 1992). This more primitive method of energy production found in cancer cells uses a fermentation cycle that requires more glucose than the cycle of a normal cell.

An enormous amount of the waste product lactic acid is produced during this kind of energy production (Schwartz, 1992). Because of the immense glucose needs of the cancer cell, the liver is stimulated by messages from the cancer cells to utilize an enzyme to convert the lactic acid waste back into more glucose (Baggetto, 1992; Waterhouse, 1974). Hence, the metabolism of carbohydrate must proceed via anaerobic glycolysis (GolshaniHebroni \& Bessman, 1997). Most of the energy demand is met by the production of ATP through glycolysis via substrate-level phosphorylation. This high glycolytic rate is important for rapidly proliferating cancer cells, not only as a major energy source, but also to provide such cells with precursors for nucleotide and lipid biosynthesis (Parry \& Pedersen, 1983). In intact glycolytic tumour cells, only $10 \%$ of the pyruvate enters a truncated Krebs cycle (Parlo \& Coleman, 1984). This results in a decline in the overall net ATP production in the host cells because of the downregulation of activity of the Krebs cycle enzymes, resulting in a loss of body weight that consequently leads to cancer cachexia (Tayek, 1992; Tisdale, 1997).

The ultimate goal of anti-neoplastic therapy is to cure cancer, thus allowing recovery. Unfortunately, non-specific cytotoxicity resulting from anti-neoplastic therapy remains a serious complication during cancer treatment, and the treatment of patients suffering from cancer cachexia becomes even more problematic. Body-wasting prior to chemotherapeutic treatment reduces expected patient survival (DeWys et al. 1980), and there is evidence that chemotherapy may directly contribute to the cachexia observed during cancer, further complicating the treatment of this disease and the patient's subsequent recovery (Le Bricon et al. 1995).

One of the hallmarks of cancer treatment is the frequent ability to achieve remission that is inevitably followed by relapse. Nutritional therapy is a key component in the treatment of cancer cachexia and in actually helping to control malignant disease in some situations (Ogilvie \& Vail, 1996). There is increasing evidence that a variety of micronutrients appear to have significant 
anti-cancer activity (Bradlow \& Sepkovic, 2002). Hence, current interest focuses on supplementation with energy-modulating vitamins (EMV; riboflavin, niacin and coenzyme $\mathrm{Q}_{10}\left(\mathrm{CoQ}_{10}\right)$ ) for the more effective management of breast cancer. Riboflavin, in its active coenzymic forms such as FMN and FAD, participates in oxidation-reduction reactions in numerous metabolic pathways and in energy production via the respiratory chain (McCormick, 1999; Powers, 1999). Niacin and its co-factors, NAD and NADP, are essential for a variety of oxidation-reduction reactions that comprise tissue respiration (Cervantes-Laurean et al. 1999; Powers, 1999). The protective effect of nicotinamide may result from its action as a free-radical scavenger and its effects on inhibition of the enzyme poly ADP-ribose synthetase and on the repletion of NAD levels inside the cell (Jacobson \& Jacobson, 1993). $\mathrm{CoQ}_{10}$ is an essential electron and protein carrier in ATP synthesis in the mitochondrial inner membrane. Besides its well-established role in energy production in aerobic organisms, $\mathrm{CoQ}_{10}$ is required for transmembrane electron transport that activates signals in the cell to stimulate cell growth (Ernster, 1977; Jolliet et al. 1998).

Our aim was to increase the amount of ATP produced via the ETC for normal host cell metabolism by enhancing the activities of the Krebs cycle and oxidative phosphorylation enzymes. For this, we made EMV available as co-factors in ETC intermediates, driving the reaction forward and preventing cancer cachexia in 7,12-dimethyl benz[a]anthracene (DMBA) induced mammary carcinoma-bearing rats.

\section{Materials and methods}

Animals

Female Sprague-Dawley albino rats between 50 and $55 \mathrm{~d}$ of age were obtained from the National Institute of Nutrition, Hyderabad, India. The animal room was well ventilated, and the animals had $12 \pm 1$ h day-night schedule throughout the experimental period. The animals were housed in large, spacious, hygienic cages and were given food and water ad libitum during the course of the experiments. The temperature was between $27^{\circ}$ and $37^{\circ} \mathrm{C}$. The studies were performed with the approval of the Institutional Animal Ethical Committee, and the care of the animals and the facility were in accordance with institutional guidelines.

\section{Experimental design}

The rats were divided into four groups, each of which contained six animals. Normal healthy controls (group I) received a single dose of olive oil $(1 \mathrm{ml})$ at the age of 8 weeks and then, after 3 months, $0.5 \mathrm{ml}$ olive oil/d orally by gastric intubation for $28 \mathrm{~d}$. Mammary carcinoma (group II) was induced with $25 \mathrm{mg} / \mathrm{ml}$ DMBA (Sigma Chemical Co., St Louis, MO, USA) in the experimental rats at 8 weeks of age, through gastric intubation (Sujatha et al. 1999). After 3 months, mammary carcinoma was confirmed by histological examination. Mammary carcinoma-induced rats were treated with the EMV riboflavin $(45 \mathrm{mg} / \mathrm{kg}$ body weight per d), niacin ( $100 \mathrm{mg} / \mathrm{kg}$ body weight per d) dissolved in water and $\mathrm{CoQ}_{10}(40 \mathrm{mg} / \mathrm{kg}$ body weight per $\mathrm{d})$ dissolved in olive oil, continued for $28 \mathrm{~d}$ daily via gastric intubation (group III). Drug control animals received the EMV in the same dosage as the animals in group III. The former animals were maintained on a normal diet and water for 3 months prior to drug ingestion (group IV).

The animal groups were formed at the same time. Other treatments were extended over time as mentioned in the text. At the termination of the study, i.e. after 3 months and $28 \mathrm{~d}$, the animals from all four groups were fasted overnight and sacrificed by cervical decapitation. Mammary gland and liver were immediately excised from the animals and weighed. Carcinomatous tissues were dissected free of grossly necrotic and haemorrhagic areas, as well as of connective tissue or normal tissue. Portions weighing approximately $500 \mathrm{mg}$ were cut, placed into plastic snap-cap vials and quickly frozen in liquid $\mathrm{N}_{2}$. The vials were placed in a deepfreezer at $-72^{\circ} \mathrm{C}$ and stored until assayed. At the time of assay, small pieces of tissue were obtained for microscopic confirmation of the diagnosis; the remainder were homogenized and used for biochemical assays.

\section{Estimation of energy-modulating vitamin status}

Riboflavin status. The most sensitive method for determining riboflavin status is measurement of the activity of erythrocyte glutathione reductase, an enzyme requiring FAD as a coenzyme. Fasting venous blood samples were collected at the end of each week. The erythrocyte glutathione reductase activity coefficient was determined according to the method of Bayoumi \& Rosalki (1976) and was calculated as the ratio of total stimulated activity in the presence of FAD in vitro to basal unstimulated activity.

Niacin status. Niacin levels in venous heparinized blood were determined according to the procedure developed by Shibata $e t$ al. (1987). This method measures free nicotinamide as well as nicotinamide derived from NAD and NADP. Blood samples were collected and stored at $-20^{\circ} \mathrm{C}$ until analysis. Nicotinamide and the internal standard 1-methylnicotinamide (Sigma Chemical Co.) were separated on a reversed-phase C-18S column $(250 \times 4.6 \mathrm{~mm}$ internal diameter; Phenomenex, Macclesfield, Cheshire, UK). The injection volume was $100 \mu \mathrm{l}$. The column was eluted isocratically at a flow rate of $1.00 \mathrm{ml} / \mathrm{min}$ at room temperature with $97 \% 10 \mathrm{mM} \mathrm{KH}_{2} \mathrm{PO}_{4}, 2.5 \%$ acetonitrile and $0.5 \%$ tetrahydrofuran at $\mathrm{pH} 4.5$. The eluent was monitored with an electrochemical detector (Dionex P580 pump, and a Dionex UVD170S UV; Dionex (UK) Ltd, Macclesfield, Cheshire, UK).

\section{Coenzyme $Q_{10}$ status}

$\mathrm{CoQ}_{10}$ plasma concentrations were determined by HPLC with UV detection, as derived from the paper by Morita \& Folkers (1993). The sample $(5-20 \mu \mathrm{l})$ was chromatographed on a reversed-phase C18 HPLC column $(250 \times 4.6 \mathrm{~mm}$; Phenomenex $)$ using a mobile phase consisting of $0.7 \% \mathrm{NaClO}_{4}$ in ethanol-methanol-70\% $\mathrm{HClO}_{4}(900: 100: 1, \mathrm{v} / \mathrm{v} / \mathrm{v})$ at a flow rate of $1.2 \mathrm{ml} / \mathrm{min}$. The eluent was monitored with an electrochemical detector (Dionex P580 pump, and a Dionex UVD170S UV; Dionex (UK) Ltd).

\section{HPLC}

HPLC was performed with an Ultracarb 5- $\mu$ m C18 column $(250 \times 4.6 \mathrm{~mm}$; Phenomenex $)$ connected to a Dionex ASI-100 automated sample injector, a Dionex P580 pump and a Dionex UVD170S UV detector (Dionex (UK) Ltd). Data were processed by Chromeleon software (Dionex (UK) Ltd). 


\section{Isolation of mitochondria from mammary gland}

Mammary glands were removed and cooled in $0.3 \mathrm{M}$ sucroseEDTA, pH 7.4, on ice. All subsequent steps were carried out at $0-4^{\circ} \mathrm{C}$. As much external connective tissue was removed as possible, and the tissues were blotted dry, weighed and minced very finely with small scissors. The tissue was then homogenized in a Potter-Elvehjem homogenizer (Sigma Chemical Co.) using two passes with a loose pestle and two passes with a tight pestle. The homogenate was strained through four layers of 10gauge cheesecloth, and the filtrate was centrifuged at $900 \mathrm{~g}$ for $5 \mathrm{~min}$. The supernatant was centrifuged at $11500 \mathrm{~g}$ for $10 \mathrm{~min}$ to sediment the mitochondria. The mitochondrial pellet was washed twice in $5 \mathrm{ml}$ sucrose-EDTA medium. At each step, the upper fatty layer was carefully removed by aspiration, and the walls of the tubes were carefully wiped clean. The final mitochondrial pellet was suspended at $10 \mathrm{mg}$ mitochondrial protein $/ \mathrm{ml}$ sucrose-EDTA $1 \%$ bovine serum albumin (BSA) medium. The purity of the mitochondria was assessed by estimating succinate dehydrogenase activity (Slater \& Bonner, 1952). Mitochondrial protein was estimated by the method of Lowry et al. (1951).

\section{Isolation of mitochondria from tumour mammary gland}

Tumour cells were identified by the appearance of a red mass under the epithelial layer of the mammary pad. Tumour mitochondria were isolated by the modified method of Senior et al. (1975). A tumour portion was removed carefully from the mammary pad and placed immediately in $0.3 \mathrm{M}$ sucrose-EDTA, $\mathrm{pH}$ $7 \cdot 4$, at $0^{\circ} \mathrm{C}$. All subsequent steps were carried out at $0-4^{\circ} \mathrm{C}$. Necrotic tissue was removed, and the tumour tissue was chopped into small pieces, weighed and washed three times with $40 \mathrm{ml}$ chilled sucrose-EDTA solution. The tumour tissue was then homogenized directly in five volumes of $0.3 \mathrm{M}$ sucrose-EDTA $/ 1 \%$ BSA, pH 7.4, in a Potter-Elvehjem homogenizer. The homogenate was then treated in the same way as the homogenate from normal mammary gland (as above). BSA is necessary to obtain functional mitochondria from the tumour.

\section{Isolation of mitochondria from liver}

Animals (experimental and controls) were decapitated, and mitochondria were isolated from the liver of all four groups using differential centrifugation according to the method of Johnson \& Lardy (1967). All operations were carried out at $0-4^{\circ} \mathrm{C}$. A $10 \%(\mathrm{w} / \mathrm{v})$ homogenate was prepared in $0.05 \mathrm{M}$ Tris- $\mathrm{HCl}$ buffer, $\mathrm{pH} 7.4$ containing $0.25 \mathrm{M}$ sucrose. The homogenates were centrifuged at $600 \mathrm{~g}$ for $10 \mathrm{~min}$, and the supernatants obtained were then centrifuged at $15000 \mathrm{~g}$ for $5 \mathrm{~min}$. Then the pellets were washed with $10 \mathrm{~mm}$ Tris- $\mathrm{HCl}(\mathrm{pH} 7.8)$ containing $0 \cdot 25 \mathrm{M}$ sucrose and finally resuspended in the same buffer.

\section{Estimation of mitochondrial Krebs cycle enzymes}

Isocitrate dehydrogenase. The enzyme activity was assayed according to the method of King (1965), with slight modification. The reaction mixture containing $0 \cdot 1 \mathrm{ml}$ Tris- $\mathrm{HCl}, 0 \cdot 2 \mathrm{ml}$ trisodium isocitrate, $0.3 \mathrm{ml}$ manganese chloride, $0.2 \mathrm{ml}$ mitochondrial suspension and $0.2 \mathrm{ml}$ NADP $(0.2 \mathrm{ml}$ water for control) was added. After $60 \mathrm{~min}$ of incubation, $1 \mathrm{ml}$ DNPH was added, followed by $0.5 \mathrm{ml}$ EDTA, and the mixture was kept at room temperature for $20 \mathrm{~min}$. Then $10 \mathrm{ml} \mathrm{NaOH}$ was added, and the colour developed was read at $390 \mathrm{~nm}$. A standard containing $\alpha$-ketoglutarate was run simultaneously.

$\alpha$-Ketoglutarate dehydrogenase. The activity of $\alpha$-ketoglutarate dehydrogenase was assayed by the method of Reed \& Mukherjee (1969). To the reaction mixture containing $0.15 \mathrm{ml}$ phosphate buffer, $0.1 \mathrm{ml}$ each of thiamine pyrophosphate, $\mathrm{MgSO}_{4}, \quad \alpha$-ketoglutarate and potassium ferrocyanide were added. The total volume was made up to $1.2 \mathrm{ml}$ with water, and $0.2 \mathrm{ml}$ mitochondrial suspension was added and incubated at $30^{\circ} \mathrm{C}$ for $20 \mathrm{~min}$. Next, $1 \mathrm{ml}$ TCA was added and centrifuged. Then, $0.2 \mathrm{ml}$ mitochondrial suspension was added to the control after the addition of TCA. Volumes of $0.1 \mathrm{ml}$ potassium ferrocyanide, $1 \mathrm{ml}$ dupanol and $0.5 \mathrm{ml}$ ferric ammonium sulphate-dupanol reagent were added to the supernatant and then incubated at $25^{\circ} \mathrm{C}$ for $20 \mathrm{~min}$. The colour developed was measured at $540 \mathrm{~nm}$. A standard containing potassium ferrocyanide was run simultaneously.

Succinate dehydrogenase. The activity of succinate dehydrogenase was assayed according to the method of Slater \& Bonner (1952). The reaction mixture, containing $1 \mathrm{ml}$ phosphate buffer, $0.1 \mathrm{ml}$ EDTA, $0.1 \mathrm{ml} \mathrm{BSA}, 0.3 \mathrm{ml}$ sodium succinate and $0.2 \mathrm{ml}$ potassium ferricyanide, was made up to $2.8 \mathrm{ml}$ with water. The reaction was started by the addition of $0.2 \mathrm{ml}$ mitochondrial suspension. The change in optical density was recorded at $15 \mathrm{~s}$ interval for $5 \mathrm{~min}$ at $420 \mathrm{~nm}$. A standard containing potassium ferrocyanide was run simultaneously.

Malate dehydrogenase. The enzyme activity was assayed by the method of Mehler et al. (1948). To $0.3 \mathrm{ml}$ buffer, $0.1 \mathrm{ml}$ $\mathrm{NADH}$ and $0.1 \mathrm{ml}$ oxaloacetate were added, the total volume being made up to $2.9 \mathrm{ml}$ with water. The reaction was started by adding $0.1 \mathrm{ml}$ mitochondrial suspension. The change in optical density was measured at $350 \mathrm{~nm}$ in intervals of $15 \mathrm{~s}$ for $5 \mathrm{~min}$ using a spectrophotometer. A standard containing potassium ferrocyanide was run simultaneously.

\section{Estimation of mitochondrial oxidative phosphorylation enzymes}

NADH dehydrogenase. The activity of NADH dehydrogenase was determined according to the method of Minakami et al. (1962), with slight modification. The reaction mixture contained $1 \mathrm{ml}$ phosphate buffer, $0.1 \mathrm{ml}$ potassium ferricyanide, $0.1 \mathrm{ml}$ $\mathrm{NADH}$ and $0.2 \mathrm{ml}$ mitochondrial suspension. The total volume was made up to $3 \mathrm{ml}$ with water. A control was also treated similarly without NADH. The change in optical density was measured at $420 \mathrm{~nm}$ as function of time for $3 \mathrm{~min}$ at $15 \mathrm{~s}$ intervals.

Cytochrome $c$ oxidase. Cytochrome c oxidase activity was assayed according to the method of Wharton \& Tzagoloff (1967), with slight modification. The reaction mixture consisted of $0.1 \mathrm{ml}$ phosphate buffer, $0.07 \mathrm{ml}$ ferrocytochrome $\mathrm{c}$ and $0.83 \mathrm{ml}$ water. The blank was oxidized with $0.01 \mathrm{ml}$ potassium ferricyanide. The reaction was then initiated by the addition of $0.01 \mathrm{ml}$ mitochondrial suspension. The decrease in absorbency was measured at $550 \mathrm{~nm}$ every $15 \mathrm{~min}$.

\section{Estimation of cellular constituents}

Extraction of nucleic acids. The nucleic acids were extracted by the method of Schneider (1957). Known amount of tissues were homogenized in $5.0 \mathrm{ml}$ ice-cold distilled water using the PotterElvehjem homogenizer with a Teflon pestle. A volume of 
$5.0 \mathrm{ml} 5 \%$ TCA was added to the homogenate, and this was kept in ice for $30 \mathrm{~min}$ to allow the complete precipitation of proteins and nucleic acids. The mixture was centrifuged and the precipitate obtained washed three times with ice-cold $10 \%$ TCA. This was then treated with $95 \%$ ethanol to remove lipids. The final precipitate was heated at $90^{\circ} \mathrm{C}$ for 15 min with occasional shaking, which facilitated the quantitative separation of nucleic acids from protein. The supernatant after centrifugation was used for the estimation of DNA and RNA.

DNA. DNA was estimated by the method of Burton (1956). A known volume of the nucleic acid extract was made up to $3.0 \mathrm{ml}$ with $1 \mathrm{M}$ perchloric acid. This was mixed with $2.0 \mathrm{ml}$ diphenylamine reagent. A reagent blank and standards were also carried out concurrently. This was kept in a boiling water bath for $10 \mathrm{~min}$, and the blue colour developed was read at $640 \mathrm{~nm}$ in a photochem colorimeter.

RNA. RNA was estimated by the method of Rawal et al. (1977). Aliquots of nucleic acid extracts were made up to $2.0 \mathrm{ml}$ with $5 \%$ TCA. To this, $3.0 \mathrm{ml}$ orcinol-ferric chloride reagent was added and mixed well. The tubes were heated in a boiling water bath for $20 \mathrm{~min}$. Reagent blank and standards were also treated in the same way. The tubes were cooled, and the colour developed was measured at $640 \mathrm{~nm}$ using a photochem colorimeter.

\section{Statistical analysis}

Values are expressed as means with their standard deviations for six rats in each group, and the significance of the differences between mean values was determined by one-way ANOVA followed by the Student's Newman Keuls for multiple comparisons using the Statistical Package for Social Sciences (SPSS Inc., Chicago, IL, USA) computer package. Values of $P<0.05$ were considered to be significant.

\section{Results}

Fig. 1 shows the body weight changes of the control and experimental rats. A growth curve was drawn between the initial and the final body weight. Initially, there was no significant change in the body weight of the control and experimental rats. Finally, however, there was a sharp drop in the body weight of the mammary carcinoma-bearing rats when compared with normal control rats. EMV-treated rats showed a gradual increase in their body weight when compared with untreated rats. Drug control rats showed an increase in their body weight but not to significant levels when compared with normal rats.

Table 1 depicts the EMV status in the blood of control and experimental rats. EMV deficiencies were observed in the mammary carcinoma-bearing rats. On combinatorial therapy, successful improvement in the status of riboflavin, niacin and $\mathrm{CoQ}_{10}$ (EMV) were observed.

The activities of mitochondrial Krebs cycle enzymes (isocitrate dehydrogenase, $\alpha$-ketoglutarate dehydrogenase, succinate dehydrogenase and malate dehydrogenase) and oxidative phosphorylation enzymes (NADH dehydrogenase and cytochrome c oxidase) in the mammary gland and liver mitochondria of control and experimental rats are depicted in Tables 2, 3 and 4. The activities of the Krebs cycle and oxidative phosphorylation enzymes are significantly $(P<0 \cdot 05)$ reduced in mammary carcinoma-bearing animals when compared with control rats. The activities of these enzymes were significantly restored to nearly normal on treatment with EMV (group III animals). In drug control (group IV) rats, there was a slight increase in the activities of Krebs cycle and oxidative phosphorylation enzymes, but not to significant levels when compared with normal (group I) rats.

Table 5 represents the levels of cellular constituents (DNA and RNA) in the mammary gland and liver of the control and experimental rats. A significant $(P<0.05)$ increase in the levels of DNA and RNA observed in mammary carcinoma-bearing rats (group II) was returned to nearly control levels upon EMV combinatorial therapy treatment (group III).

\section{Discussion}

The goal of the experiment was to focus on cancer cachexia and to move toward a consensus statement on the role of EMV in prevention and treatment of breast cancer. The biochemical changes in the activities of various enzymes reflect the extent of metabolic alterations caused by the tumour.

In mammary carcinoma-bearing rats, there was a sharp decline in body weight. Weight loss is one of the most frequent adverse systemic effects of malignancy (DeWys et al. 1980). A decline in food intake relative to energy expenditure is the fundamental physiological derangement leading to cancer-associated weight loss (Pain et al. 1984; Mulligan \& Tisdale, 1991). Combinatorial therapy-extended rats showed a significant increase in their body weight when compared with the untreated tumour-induced

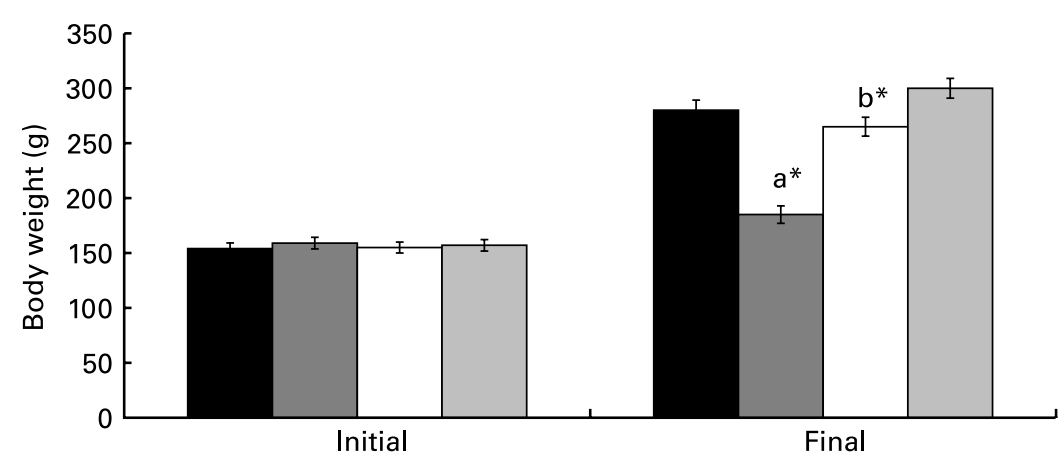

Fig. 1. Effect of enzyme-modulating vitamins (EMV) on the body weight changes in control and experimental rats. Body weight changes were observed from the initial and final days of drug treatment. Values are means for six rats per group with their standard deviation shown by vertical bars. For statistical evaluation of

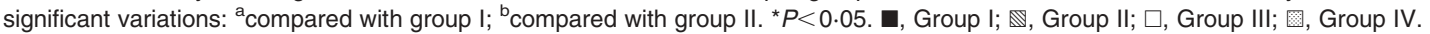


Table 1. Effect of energy-modulating vitamins (EMV) on the status of riboflavin, niacin and coenzyme $\left(\mathrm{CoQ}_{10}\right)$ in the blood of control and experimental rats

(Values expressed as means with their standard deviations for six rats)

\begin{tabular}{|c|c|c|c|c|c|c|c|c|}
\hline \multirow[b]{2}{*}{ Parameters } & \multicolumn{2}{|c|}{ Group I (control) } & \multicolumn{2}{|c|}{$\begin{array}{c}\text { Group II (DMBA } \\
\text { induced) }\end{array}$} & \multicolumn{2}{|c|}{$\begin{array}{l}\text { Group III (DMBA } \\
\text { induced + EMV) }\end{array}$} & \multicolumn{2}{|c|}{$\begin{array}{c}\text { Group IV } \\
\text { (control + EMV) }\end{array}$} \\
\hline & Mean & SD & Mean & SD & Mean & SD & Mean & SD \\
\hline Riboflavin (EGRAC) & 1.09 & 0.089 & 0.71 & $0.056^{a *}$ & 0.92 & $0.081^{b *}$ & $1 \cdot 12$ & 0.094 \\
\hline Niacin $(\mu \mathrm{g} / \mathrm{ml})$ & $42 \cdot 6$ & 3.29 & $27 \cdot 4$ & $2 \cdot 11^{\mathrm{a} *}$ & $36 \cdot 1$ & $2 \cdot 98^{\mathrm{b} *}$ & 43.7 & 3.62 \\
\hline $\mathrm{CoQ}_{10}(\mu \mathrm{g} / \mathrm{ml})$ & 21.9 & $2 \cdot 38$ & $14 \cdot 2$ & $1 \cdot 27^{\mathrm{a} *}$ & $19 \cdot 1$ & $1.69^{\mathrm{b} *}$ & $23 \cdot 1$ & $2 \cdot 19$ \\
\hline
\end{tabular}

DMBA, 7,12-dimethyl benz[a]anthracene; EGRAC, erythrocyte glutathione reductase activation coefficient.

Comparisons were made between ${ }^{\mathrm{a}}$ groups I and II, ${ }^{\mathrm{b}}$ groups II and III, and ${ }^{\mathrm{c}}$ groups I and IV.

* $P<0.05$

Table 2. Effect of energy-modulating vitamins (EMV) on the activities of Krebs cycle enzymes in the mammary gland mitochondria of control and experimental rats

(Values expressed as means with their standard deviations for six rats)

\begin{tabular}{|c|c|c|c|c|c|c|c|c|}
\hline \multirow[b]{2}{*}{ Parameters (Units/mg protein) } & \multicolumn{2}{|c|}{ Group I (control) } & \multicolumn{2}{|c|}{$\begin{array}{c}\text { Group II (DMBA } \\
\text { induced) }\end{array}$} & \multicolumn{2}{|c|}{$\begin{array}{l}\text { Group III (DMBA } \\
\text { induced + EMV) }\end{array}$} & \multicolumn{2}{|c|}{$\begin{array}{c}\text { Group IV (Control } \\
+ \text { EMV) }\end{array}$} \\
\hline & Mean & SD & Mean & SD & Mean & SD & Mean & SD \\
\hline Isocitrate dehydrogenase $\dagger$ & 531.9 & 39.62 & 389.55 & $21 \cdot 79^{\mathrm{a*}}$ & $515 \cdot 48$ & $32 \cdot 37^{\mathrm{b} *}$ & $540 \cdot 07$ & 34.59 \\
\hline$\alpha$-Ketoglutarate dehydrogenase $\ddagger$ & 174.06 & 11.98 & 99.74 & $7.91^{\mathrm{a}^{*}}$ & $140 \cdot 66$ & $10 \cdot 71^{\mathrm{b}^{*}}$ & $179 \cdot 19$ & 12.01 \\
\hline Succinate dehydrogenase $\S$ & $236 \cdot 11$ & $19 \cdot 15$ & $159 \cdot 32$ & $11 \cdot 72^{\mathrm{a} *}$ & $210 \cdot 65$ & $16 \cdot 92^{b *}$ & 241.55 & 19.02 \\
\hline Malate dehydrogenase\| & 3572 & $96 \cdot 12$ & 2378 & $84.56^{\mathrm{a} *}$ & 3096 & $99 \cdot 07^{\mathrm{b} *}$ & 3609 & 89.92 \\
\hline
\end{tabular}

DMBA, 7,12-dimethyl benz[a]anthracene.

Comparisons were made between a groups I and II, bgroups II and III, and cgroups I and IV.

$\dagger \mathrm{nmol} \alpha$-ketoglutarate dehydrogenase liberated $/ \mathrm{min} / \mathrm{mg}$ mitochondrial protein; $\ddagger \mu \mathrm{mol}$ ferrocyanide liberated $/ \mathrm{min} / \mathrm{mg}$ mitochondrial protein; § $\mu \mathrm{mol}$ succinate oxidized/min/mg mitochondrial protein; $\| \mathrm{nmol} \mathrm{NADH}$ oxidized/min/mg mitochondrial protein.

${ }^{*} P<0.05$.

animals. This positive modulation could be attributed to the presence of co-factors in the combinatorial therapy that participate in the ETC to enhance ATP production, thereby improving body weight in the host tissue to prevent cancer cachexia.

Cancer patients are frequently malnourished, and micronutrient deficiency is an important and understudied problem (Inculet $e t$ al. 1987, Shike \& Brennan, 1993). In our study, EMV status was found to be significantly decreased in carcinoma-bearing rats. During treatment with EMV, the levels of EMV were found to be normalized. Several studies indicate that supplementation with riboflavin inhibits tumour growth in experimental animals and possibly in man, but the precise mechanisms involved have not been elucidated (Kensler et al. 1941; Wahrendorf et al. 1988). Niacin is one of the nutrients that appears to be deficient in many cancers (Inculet et al. 1987) and in chemotherapy patients (Dreizen et al. 1990). Biochemically and nutritionally, cancer patients would have an impaired biosynthesis of $\mathrm{CoQ}_{10}$, and the subsequent deficiency of $\mathrm{CoQ}_{10}$ could be a dominant biochemical dysfunction. It is therefore expected that many cancer patients will have abnormally low levels of $\mathrm{CoQ}_{10}$ in their blood and tissue (Folkers et al. 1993, 1997). Exogenous $\mathrm{CoQ}_{10}$ administration via the nutrition may help to increase the

Table 3. Effect of energy-modulating vitamins (EMV) on the activities of Krebs cycle enzymes in the liver mitochondria of control and experimental rats

(Values expressed as means with their standard deviations for six rats)

\begin{tabular}{|c|c|c|c|c|c|c|c|c|}
\hline \multirow[b]{2}{*}{ Parameters (Units/mg protein) } & \multicolumn{2}{|c|}{ Group I (control) } & \multicolumn{2}{|c|}{$\begin{array}{l}\text { Group II (DMBA } \\
\text { induced) }\end{array}$} & \multicolumn{2}{|c|}{$\begin{array}{l}\text { Group III (DMBA } \\
\text { induced + EMV) }\end{array}$} & \multicolumn{2}{|c|}{$\begin{array}{c}\text { Group } \\
\mathrm{IV}(\text { control }+ \text { EMV })\end{array}$} \\
\hline & Mean & SD & Mean & SD & Mean & SD & Mean & SD \\
\hline Isocitrate dehydrogenase $\dagger$ & $726 \cdot 88$ & $42 \cdot 13$ & $484 \cdot 17$ & $35 \cdot 11^{\mathrm{a} *}$ & 689.59 & $41 \cdot 21^{\mathrm{b} *}$ & 731.59 & $48 \cdot 20$ \\
\hline$\alpha$-Ketoglutarate dehydrogenase $\ddagger$ & $152 \cdot 72$ & $12 \cdot 01$ & 96.65 & $08.44^{\mathrm{a} *}$ & $138 \cdot 34$ & $10 \cdot 22^{b *}$ & 161.06 & $12 \cdot 31$ \\
\hline Succinate dehydrogenase§ & 78.44 & 8.78 & $42 \cdot 14$ & $4.57^{a *}$ & $69 \cdot 42$ & $5 \cdot 09^{\mathrm{b} *}$ & $82 \cdot 37$ & 9.00 \\
\hline Malate dehydrogenase\| & $277 \cdot 88$ & 21.58 & 178.51 & $12 \cdot 27^{\mathrm{a} *}$ & $259 \cdot 22$ & $22 \cdot 41^{\mathrm{b} *}$ & 311.47 & $27 \cdot 64$ \\
\hline
\end{tabular}

DMBA, 7,12-dimethyl benz[a]anthracene.

$\dagger \mathrm{nmol} \alpha$-ketoglutarate dehydrogenase liberated/min/mg mitochondrial protein; $\ddagger \mu \mathrm{mol}$ ferrocyanide liberated/min/mg mitochondrial protein; § $\mu \mathrm{mol}$ succinate oxidized/min/mg mitochondrial protein; \|nmol NADH oxidized/min/mg mitochondrial protein.

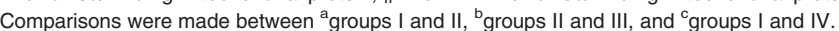
${ }^{\star} P<0.05$ 
Table 4. Effect of energy-modulating vitamins (EMV) on the activities of oxidative phosphorylation enzymes in the mammary gland and liver mitochondria of control and experimental rats

(Values expressed as means with their standard deviations for six rats)

\begin{tabular}{|c|c|c|c|c|c|c|c|c|}
\hline \multirow[b]{2}{*}{ Parameters (Units/mg protein) } & \multicolumn{2}{|c|}{ Group I (control) } & \multicolumn{2}{|c|}{$\begin{array}{c}\text { Group II (DMBA } \\
\text { induced) }\end{array}$} & \multicolumn{2}{|c|}{$\begin{array}{l}\text { Group III (DMBA } \\
\text { induced + EMV) }\end{array}$} & \multicolumn{2}{|c|}{$\begin{array}{c}\text { Group IV } \\
\text { (control + EMV) }\end{array}$} \\
\hline & Mean & SD & Mean & SD & Mean & SD & Mean & SD \\
\hline \multicolumn{9}{|l|}{ Mammary gland } \\
\hline $\mathrm{NADH}$ dehydrogenase $\dagger$ & $15 \cdot 06$ & 0.92 & $9 \cdot 33$ & $0.63^{\mathrm{a} *}$ & $13 \cdot 89$ & $0.78^{\mathrm{b} *}$ & $15 \cdot 19$ & 0.96 \\
\hline Cytochrome c oxidase $\neq$ & 3.64 & 0.14 & 1.97 & $0 \cdot 10^{\mathrm{a} *}$ & 3.24 & $0 \cdot 19^{\mathrm{b} *}$ & 3.69 & 0.15 \\
\hline \multicolumn{9}{|l|}{ Liver } \\
\hline NADH dehydrogenase & $27 \cdot 59$ & 1.72 & $14 \cdot 03$ & $1 \cdot 01^{a *}$ & $26 \cdot 13$ & $1.94^{\mathrm{b} *}$ & 28.09 & 1.96 \\
\hline Cytochrome c oxidaseł & 7.02 & 0.34 & 3.22 & $0.30^{\mathrm{a} *}$ & 6.44 & $0.49^{b *}$ & $7 \cdot 15$ & 0.51 \\
\hline
\end{tabular}

DMBA, 7,12-dimethyl benz[a]anthracene.

$\dagger \mu \mathrm{mol} \mathrm{NADH}$ oxidized $/ \mathrm{min} / \mathrm{mg}$ mitochondrial protein; foptical density $\times 10^{-2} / \mathrm{min} / \mathrm{mg}$ mitochondrial protein.

Comparisons were made between ${ }^{\mathrm{a}}$ groups I and II, ${ }^{\mathrm{b}}$ groups II and III, and ${ }^{\circ}$ groups I and IV.

${ }^{*} P<0.05$.

protective effect of $\mathrm{CoQ}_{10}$ in breast tissue, especially in women in the high-risk group (Jolliet et al. 1998). Furthermore, $\mathrm{CoQ}_{10}$ has been shown to extend the lifespan of laboratory animals (Sarter, 2000). Our findings are also consistent with the above reports.

Most cancers probably start with an interruption of the Krebs cycle that arrests aerobic metabolism and forces the cell to revert back to anaerobic metabolism. In the present study, mammary carcinoma-induced rats showed a significant reduction in the activities of the Krebs cycle enzymes. Reductions in the activities of Krebs cycle enzymes prove the defect in the aerobic oxidation of pyruvate that might cause the low production of ATP molecules; this observation tallies with that by Hennipman et al. (1988).

Isocitrate dehydrogenase requires NAD and NADP as electron acceptors in the citric acid cycle to produce ATP molecules via oxidative phosphorylation (Damle et al. 1971). $\alpha$-Ketoglutarate dehydrogenase requires five coenzymes for its activity: thiamine pyroposphate, lipoic acid, FAD, coenzyme A and NAD (Greenhouse \& Lehninger, 1977). In the cancerous condition, the supply of these co-factors is inadequate. On EMV supplementation, these enzyme activities were significantly elevated; which could be due to the availability of co-factors FAD, NAD and NADP from riboflavin and niacin in the treatment regimen.
Succinate dehydrogenase is an integral part of the inner mitochondrial membrane and is directly linked to the ETC. The oxidation of succinate to produce $\mathrm{FADH}_{2}$ molecules that directly transfer the electrons to ubiquinone results in the generation of two ATP molecules (Tchen \& van Milligan, 1960). Malate dehydrogenase is an oxidoreductase and a highly stereospecific NADrequiring enzyme that specifically catalyses an important reaction in the Krebs cycle, which is important in cellular metabolism and energy production (Dietzen \& Davis, 1993). When cancer was present, the activities of these enzymes were found to be reduced. On EMV treatment, these enzyme activities were significantly elevated, which could be mainly due to the supply of NAD through niacin.

The enzymes located in the mitochondria catalyse the oxidation of a number of substrates via the Krebs cycle, yielding reducing equivalents. These reducing equivalents are channelled through the respiratory chain for the synthesis of ATP, the energy currency of the cell produced by oxidative phosphorylation, which provides the energy needed for many cellular functions. The processes leading to the Krebs cycle and the Krebs cycle itself proceed in a way that produces two very simple forms of proton donor, $\mathrm{NADH}$ and $\mathrm{FADH}$. These then react with $\mathrm{O}_{2}$ to yield electrons in the inner membrane, and these in turn carry out the work of oxidative phosphorylation with the help of CoQ

Table 5. Effect of energy-modulating vitamins (EMV) on the levels of cellular constituents in the mammary gland and liver of control and experimental rats

(Values expressed as means with their standard deviations for six rats)

\begin{tabular}{|c|c|c|c|c|c|c|c|c|}
\hline \multirow[b]{2}{*}{ Parameters (mg/g wet tissue) } & \multicolumn{2}{|c|}{ Group I (control) } & \multicolumn{2}{|c|}{$\begin{array}{l}\text { Group II (DMBA } \\
\text { induced) }\end{array}$} & \multicolumn{2}{|c|}{$\begin{array}{l}\text { Group III (DMBA } \\
\text { induced + EMV) }\end{array}$} & \multicolumn{2}{|c|}{$\begin{array}{c}\text { Group IV } \\
\text { (control + EMV) }\end{array}$} \\
\hline & Mean & SD & Mean & SD & Mean & SD & Mean & SD \\
\hline \multicolumn{9}{|l|}{ Mammary gland } \\
\hline DNA & 3.92 & 0.21 & $5 \cdot 16$ & $0.60^{\mathrm{a} *}$ & $4 \cdot 27$ & $0.28^{\mathrm{b} *}$ & $3 \cdot 88$ & 0.26 \\
\hline RNA & 1.82 & 0.11 & $2 \cdot 64$ & $0.19^{a *}$ & 2.06 & $0.16^{\mathrm{b} *}$ & $1 \cdot 81$ & 0.15 \\
\hline \multicolumn{9}{|l|}{ Liver } \\
\hline DNA & $5 \cdot 08$ & 0.39 & $6 \cdot 14$ & $0.42^{\mathrm{a} *}$ & $5 \cdot 47$ & $0.36^{\mathrm{b} *}$ & 5.02 & 0.33 \\
\hline RNA & $2 \cdot 17$ & 0.28 & 3.29 & $0.31^{a *}$ & 2.59 & $0.17^{\mathrm{b} *}$ & $2 \cdot 12$ & 0.19 \\
\hline
\end{tabular}

DMBA, 7,12-dimethyl benz[a]anthracene;

Comparisons were made between ${ }^{\mathrm{a}}$ groups I and II, ${ }^{\mathrm{b}}$ groups II and III, and ${ }^{\mathrm{c}}$ groups I and IV. ${ }^{\star} P<0.05$. 
and the cytochromes (Williamson \& Copper, 1980; Tzagoloff, 1982). DMBA-treated animals showed a decline in their level of ATP production that might be due to the inhibition of Krebs cycle and oxidative phosphorylation enzymes. The inhibition of these enzymes may affect mitochondrial substrate oxidation, resulting in a reduced oxidation of substrates, a reduced rate of transfer of reducing equivalents to molecular $\mathrm{O}_{2}$ and the depletion of energy production.

NADH dehydrogenase, a flavin-linked dehydrogenase, constitutes complex I of the ETC, which passes electrons from NADH to CoQ. Cytochrome c oxidase (complex IV) donates electrons directly to molecular $\mathrm{O}_{2}$. The significant decline in the activities of these key oxidative phosphorylation enzymes in cancer would result in the inhibition of electron flow from NADH to $\mathrm{O}_{2}$. The decrease in activity of NADH dehydrogenase may be due to a depletion of reducing equivalents such as NADH and NADPH (Pederson, 1978; Baggetto, 1993).

The relative concentrations of NAD and NADH are important in regulating energy metabolism. When the NAD:NADH ratio is high, the rate of Krebs cycle increases. However, the activity of this cycle is slowed down when the NAD:NADH ratio is low because of an insufficient NAD concentration for normal enzymatic function and the reoxidation of NADH coupled to ATP formation. Intracellular levels of the NAD can be effectively increased by the addition of the NAD precursors nicotinic acid and nicotinamide from niacin through EMV supplementation. In addition, $\mathrm{CoQ}_{10}$ enhances the activity of ETC complexes and produces a large amount of ATP because it enhances the activity of ubiquinone complex, which serves as a highly mobile electron carrier between the flavoproteins and cytochromes of the ETC (Ernster, 1977).

The major mechanism involved in cancer cells reverting back to aerobic metabolism, and thus back to normal cells, has three basic stages: enhancement of the Krebs cycle, of the respiratory chain enzyme activities and of $\mathrm{O}_{2}$ transport to the cells. On EMV supplementation, these enzyme activities were significantly increased, which clearly indicates the reversal of cancer cells to normal ones. This effect could be due to the supply of co-factors (FMN, FAD, NAD, NADP and CoQ) by EMV, which participate in oxidation-reduction reactions in numerous metabolic pathways and enhance the activity of the Krebs cycle and respiratory chain enzymes (Koroshetz et al. 1997; Powers, 1999). One would expect the anaerobic metabolism to cause the breast cancer owing to the lack of $\mathrm{CoQ}_{10}$; when the latter was replenished, aerobic metabolism would restart and the cancer cells revert to normal cells (Lockwood et al. 1994). Although glycolysis provides some of the ATP needed by the cell, the major generation of ATP occurs during oxidative phosphorylation in the mitochondria of mammalian cells, as electrons are transferred from NADH, FADH to $\mathrm{O}_{2}$ by a series of electron-carriers. NADH is reconverted to NAD, with the concomitant conversion of ADP to ATP (Coper \& Neubert, 1964). In addition to their central role in energy metabolism, EMV supply the necessary co-factors that function as coenzymes in critical biochemical reactions facilitating ATP production. EMV play a diverse and critical role in many metabolic pathways and are thus vital in supplying energy and maintaining the integrity of the surrounding normal cells, preventing cancer cachexia.

DNA damage is a sensitive indicator and a potential biological target for many initiators of carcinogenesis (Shang Zhang et al. 1991). Persistent basal DNA damage may reflect higher exposure to carcinogens and deficient DNA repair (Rajeswari et al. 2000). Higher levels of DNA adduct and oxidative base lesions have been reported in the normal adjacent and tumour tissues of breast cancer patients ( $\mathrm{Li}$ et al. 1999). These findings suggest that an accumulation of DNA damage may contribute to breast carcinogenesis. The binding of DMBA to cellular DNA indicates the DMBA-DNA interactions and is responsible for initiation of carcinogenic processes. Hence, the determination of DNA content plays an important role in tumorigenesis (Lin et al. 2001). RNA levels were also found to be increased in the cancerous condition; as DNA and RNA are directly related to each other, the abnormal increased content of DNA may lead to an increased transcription that leads to the increased RNA content of tumour cells. Palani et al. (1999) have reported an increased amount of DNA and RNA in fibrosarcoma-bearing rats. Our findings are also in line with the above reports.

With EMV combinatorial therapy, the levels of DNA and RNA were found to be nearly normal, which hints at the anti-tumour property of the drugs that inhibits the progression of tumour growth, as the size of the tumour is well correlated with the tumour's DNA content in malignant conditions. The inhibitory activity on tumour growth may be due to the multiple co-factors present in the drug. Pangrekar et al. (1993) reported that riboflavin could reduce carcinogen-DNA interaction. Niacin (co-factor NAD) is important in modulating ADP ribose polymer metabolism, cyclic ADP ribose synthesis and stress response proteins, such as p53, following DNA damage. Understanding how NAD metabolism is regulated in human subjects has important implications for developing both prevention and treatment strategies against carcinogenesis (Jacobson, 1993; Jacobson \& Jacobson, 1993; Jacobson et al. 1999). Folkers et al. (1993) reported several case histories of cancer patients with prolonged survival on therapy with $\mathrm{CoQ}_{10}$. More recent findings substantiate the view that supplementation with $\mathrm{CoQ}_{10}$ can cause a complete regression of tumours in advanced breast cancer, including one patient with numerous metastases to the liver (Lockwood et al. 1994, 1995; Diamond et al. 1997).

In conclusion, the above findings indicate that net ATP production was diminished in tumour-bearing animals, which ultimately leads to cancer cachexia. Treatment with EMV enhanced the activities of the Krebs cycle enzymes, and oxidative phosphorylation as a consequence enhanced ATP production. This increased amount of ATP was utilized by normal cells for their routine metabolism, reducing the cancer cachexia. In addition, the anti-carcinogenic and anti-proliferative effects of EMV suppress tumour cell proliferation. This suggests that the new combination of EMV could be of major therapeutic value in breast cancer management.

\section{Acknowledgements}

Financial assistance from the University Grant Commission (UGC) Major Research Project, New Delhi, India is gratefully acknowledged.

\section{References}

Baggetto LG (1992) Deviant energetic metabolism of glycolytic cancer cells. Biochimie 74, 959-974.

Baggetto LG (1993) Role of mitochondria in carcinogenesis. Eur J Cancer 29, 156-159. 
Bayoumi RA \& Rosalki SB (1976) Evaluation of methods of coenzyme activation of erythrocyte enzymes for detection of deficiency of vitamins B1, B2 and B6. Clin Chem 22, 327-335.

Bradlow HL \& Sepkovic DW (2002) Diet and breast cancer. Ann NY Acad Sci 963, 247-267.

Burton K (1956) A study of the conditions and mechanism of the diphenylamine reaction for the colorimetric estimation of deoxyribonucleic acid. Biochem J 62, 315-323.

Cervantes-Laurean D, McElvaney NG \& Moss J (1999) Niacin. In Modern Nutrition in Health and Disease, pp. 401-411 [ME Shils, JA Olson, M Shike and AC Ross, editors]. Baltimore, MD: Williams \& Wilkins.

Coper H \& Neubert D (1964) Effect of NAD and other NAD analogues on the formation of NADPH and its transphosphorylation to ATP. Biochim Biophys Acta 82, 167-170.

Damle SR, Talavdekar RV \& Panse TB (1971) The studies on glycolytic enzymes in relation to cancer. II. Comparative study of phosphohexoseisomerase, aldolase, isocitric dehydrogenase, serum glutamic oxaloacetic and pyruvic transaminase, and alkaline phosphatase in liver. Ind $J$ Cancer 8, 21-29.

DeWys WD, Begg C, Lavin PT et al. (1980) Prognostic effect of weight loss prior to chemotherapy in cancer patients. Am J Med 69, 491-497.

Diamond WJ, Cowden WL \& Goldberg B (1997) An alternative medicine definitive guide to cancer. Tiburon, Califormia: Future Medicine Publishing.

Dietzen DJ \& Davis EJ (1993) Oxidation of pyruvate, malate, citrate, and cytosolic reducing equivalents by AS-30D hepatoma mitochondria. Arch Biochem Biophys 305, 91-102.

Dreizen S, McCredie KB, Keating MJ \& Andersson BS (1990) Nutritional deficiencies in patients receiving cancer chemotherapy. Postgrad Med 87, 163-167.

Ernster L (1977) Facts and ideas about the function of coenzyme Q10 in the mitochondria. In Biomedical and Clinical Aspects of Coenzyme Q, pp. 15-18 [K Folkers and Y Yamamura, editors]. Amsterdam: Elsevier.

Folkers K, Brown R, Judy WV \& Morita M (1993) Survival of cancer patients on therapy with coenzyme Q10. Biochem Biophys Res Commun 192, 241-245.

Folkers K, Osterborg A, Nylander M, Morita M \& Mellstedt H (1997) Activities of vitamin $\mathrm{Q}_{10}$ in animal models and a serious deficiency in patients with cancer. Biochem Biophys Res Commun 234, 296-299.

Golshani-Hebroni SG \& Bessman SP (1997) Hexokinase binding to mitochondria: a basis for proliferative energy metabolism. J Bioenerg Biomemb 29, 331-338.

Greenhouse WV \& Lehninger AL (1977) Magnitude of malate-aspartate reduced nicotinamide adenine dinucleotide shuttle activity in intact respiring tumor cells. Cancer Res 37, 4173-4181.

Hennipman A, Van Oirschot BS, Smit J, Rijsken G \& Stacil GE (1988) Heterogenicity of glycolytic enzyme activity and isozyme composition of pyruvate kinase in breast cancer. Tumour Biol 9, 178-189.

Inculet RI, Norton JA, Nichoalds GE, Maher MM, White DE \& Brennan MF (1987) Water-soluble vitamins in cancer patients on parenteral nutrition: a prospective study. JPEN J Parenter Enteral Nutr 11, 243-249.

Jacobson E (1993) Niacin deficiency and cancer in women. J Am Coll Nutr 12, 412-416.

Jacobson EL \& Jacobson MK (1993) A biomarker for the assessment of niacin nutriture as a potential preventive factor in carcinogenesis. J Int Med 233, 59-62.

Jacobson EL, Shieh WM \& Huang AC (1999) Mapping the role of NAD metabolism in prevention and treatment of carcinogenesis. Mol Cell Biochem 193, 69-74.

Johnson D \& Lardy H (1967) Isolation of liver or kidney mitochondria. Methods Enzymol 10, 94-96.

Jolliet P, Simon N, Barre J, Boukef JY, Paniel BJ \& Tillement JP (1998) Plasma co-enzyme $\mathrm{Q}_{10}$ concentration in breast cancer: prognosis and therapeutic consequence. Int J Clin Pharm Ther 36, 506-509.
Kensler CJ, Sugiura K, Young NF, Halter CR \& Rhoads CP (1941) Partial protection of rats by riboflavin with casein against liver cancer caused by dimethylaminoazobenzene. Science 93, 308-310.

King J (1965) Transferases. In Practical clinical enzymology, p. 263 [D Van Nostrand, editor]. London NJ: Nostrand Company Ltd.

Koroshetz WJ, Jenkins BG, Rosen BR \& Beal MF (1997) Energy metabolism defects in Huntington's disease and effects of coenzyme Q10. Ann Neurol 41, 160-165.

Le Bricon T, Gugins S, Cynober L \& Baracos VE (1995) Negative impact of cancer chemotherapy on protein metabolism in healthy and tumorbearing rats. Metabolism 44, 1340-1348.

Li D, Zhang W, Sahin AA \& Hittelman WN (1999) DNA adducts in normal tissue adjacent to breast cancer: a review. Cancer Detect Prev 23, 454-462.

Lin CC, Lu YP, Lou YR, Ho CT, Newmark H, MacDonald C, Singletary KW \& Huang MT (2001) Inhibition by dietary dibenzoylmethane of mammary gland proliferation, formation of DMBA-DNA adducts in mammary glands, and mammary tumorigenesis in Sencar mice. Cancer Lett 168, 125-132.

Lockwood K, Moesgaard S \& Folkers K (1994) Partial and complete regression of breast cancer in patients in relation to dosage of coenzyme Q10. Biochem Biophys Res Comm 199, 1504-1508.

Lockwood K, Moesgaard S, Yamamoto T \& Folkers K (1995) Progress on therapy of breast cancer with vitamin Q10 and the regression of metastases. Biochem Biophys Res Commun 212, 172-177.

Lowry OH, Rosebrough NJ, Farr AL \& Randall RJ (1951) Protein measurement with folin-phenol reagent. J Biol Chem 193, 265-275.

McCormick DB (1999) Riboflavin. In Modern Nutrition in Health and Disease, pp. 391-399 [ME Shils, JA Olson, M Shike and AC Ross, editors]. Baltimore: Williams \& Wilkins.

Mehler AH, Kornberg A, Grisolia S \& Ochoa S (1948) The enzymatic mechanisms of oxidation reduction between malate or isocitrate and pyruvate. J Biol Chem 174, 961-977.

Minakami S, Ringer RL \& Singer TP (1962) Studies on respiratory chain linked dihydrodiphosphopyridine nucleotide dehydrogenase. J Biol Chem 237, 569-576.

Morita M \& Folkers K (1993) A new method to determine the level of coenzyme Q10 in one drop of human blood for biomedical research. Biochem Biophys Res Commun 191, 950-995.

Mulligan HD \& Tisdale MJ (1991) Metabolic substrate utilization by tumour and host tissues in cancer cachexia. Biochem $J \mathbf{2 7 7}$, $321-326$.

Ogilvie GK \& Vail DM (1996) Metabolic alterations and nutritional therapy for the veterinary cancer patient. In Clinical Veterinary Oncology, [SJ Withrow and EG MacEwen, editors]. Philadelphia: WB Saunders.

Pain VM, Randall DP \& Garlick PJ (1984) Protein synthesis in liver and skeletal muscle of mice bearing ascites tumour. Cancer Res $\mathbf{4 4}$, 1054-1057.

Palani V, Senthilkumaran RK \& Govindasamy S (1999) Biochemical evaluation of antitumour effect of Muthu Marunthu (a herbal formulation) on experimental fibrosarcoma in rats. Toxicol Pathol 12, 162-166.

Pangrekar J, Krishnaswamy K \& Jagadeesan V (1993) Effects of riboflavin deficiency and riboflavin administration on carcinogen-DNA binding. Chem Toxicol 31, 745-750.

Parlo RA \& Coleman PS (1984) Enhanced rate of citrate export from cholesterol-rich hepatoma mitochondria. The truncated krebs cycle and other metabolic ramification of mitochondrial membrane cholesterol. J Biol Chem 259, 9997-10003.

Parry DM \& Pedersen PL (1983) Intracellular localization and properties of particulate hexokinase in the Novikoof ascites tumour: evidence for an outer mitochondrial membrane location. J Biol Chem 258 , 10904-10912.

Pederson PL (1978) Tumor mitochondria and the bioenergetics of cancer cells. Prog Exp Tumor Res 22, 190-274.

Powers HJ (1999) Current knowledge concerning optimal nutrition status of riboflavin, niacin and pyridoxin. Proc Nutr Soc 58, 435-440. 
Rajeswari N, Ahuja YR, Malini U, Chandrashekar S, Balakrishna N, Rao KV \& Khar A (2000) Risk assessment in first degree female relatives of breast cancer patients using the alkaline Comet assay. Carcinogenesis 21, 557-561.

Rawal UM, Patel US, Rao GN \& Desai RR (1977) Clinical and biochemical studies on cataractous human lens III. Quantitative study of protein, RNA and DNA. Arogya J Health Sci 3, 69-72.

Reed LJ \& Mukherjee BB (1969) $\alpha$-Ketoglutarate dehydrogenase complex from Escherichia coli. Methods Enzymol 13, 55-61.

Sarter B (2000) Coenzyme $\mathrm{Q}_{10}$ and cardiovascular disease: a review. J Cardiovasc Nurs 16, 9-20.

Schneider WC (1957) Determination of nucleic acids in tissues by pentose analysis. Meth Enzymol, 3, 680-684.

Schwartz MK (1992) Enzymes as prognostic markers and therapeutic indicators in patients with cancer. Clin Chim Acta 206, 77-82.

Senior AE, McGowan SE \& Hilf R (1975) A comparative study of inner membrane enzymes and transport systems in mitochondria from R3230AC mammary tumor and normal rat mammary gland. Cancer Res 35, 2061-2067.

Shang Zhang J, Xu Y, Sattler LG \& Pilot CH (1991) DNA damage and repair in $\gamma$-glutamyl transpeptidase-positive and negative hepatocytes in primary culture from carcinogen treated rats. Proc Soc Exp Biol Med 196, 47-53.

Shibata K, Kawada T \& Iwai K (1987) High performance liquid chromatographic determination of nicotinamide in rat tissue samples and blood after extraction with diethylether. J Chromatogr 422, 257-262.

Shike M \& Brennan MF (1993) Supportive care of the cancer patient nutritional support. In Cancer: Principles and Practice of Oncology, pp. 2029-2044 [VT DeVita, S Hellman and SA Rosenberg, editors] Philadelphia: JB Lippincott.

Singh KK (2000) Mitochondrion: me and the mitochondrial journal. Mitochondrion 1, 1-2.

Slater EC \& Bonner WD (1952) Effect fluoride on succinate oxidase system. Biochem J 52, 185-196.

Sujatha V, Muthumanickam V, Rani G \& Sachdanandam P (1999) Effect of Semecarpus anacardium Linn. nut extract on glucose metabolizing enzymes in experimentally induced mammary carcinoma in rats. J Pharm Pharmacol 51, 241.

Tayek JA (1992) A review of cancer cachexia and abnormal glucose metabolism in humans with cancer. J Am Coll Nutr 11, 45-56.

Tchen TT \& van Milligan H (1960) The stereospecificity of the succinate dehydrogenase reaction. J Am Chem Soc 82, 4115-4116.

Tisdale MJ (1997) Biology of cachexia. J Natl Cancer Inst 89 $1763-1773$.

Tzagoloff A (1982) Oxidative pathways in mitochondria. In Mitochondria, pp. 39-60 [P Siekevitz, editor]. New York: Plenum Press.

Wahrendorf J, Munoz N \& Lu JB (1988) Blood, retinol and zinc riboflavin status in relation to precancerous lesions of the esophagus: findings from a vitamin intervention trial in the People's Republic of China. Cancer Res 48, 2280-2283.

Waterhouse C (1974) Lactate metabolism in patients with cancer cachexia. Cancer 33, 66-71.

Wharton DC \& Tzagoloff A (1967) Cytochrome oxidase from beef heart mitochondria. Methods Enzymol 10, 245-250.

Williamson J \& Copper R (1980) Regulation of the citric acid cycle in mammalian systems. FEBS Lett 117, 73-85. 